\title{
СЖИГАНИЕ МОДЕЛЬНЫХ И РЕАЛЬНЫХ НЕФТЕШЛАМОВ В КИПЯЩЕМ СЛОЕ КАТАЛИЗАТОРА
}

\author{
Дубинин Юрий Владимирович',
} dubinin@catalysis.ru

\author{
Языков Николай Алексеевич', \\ yazykov@catalysis.ru
}

\section{Симонов Александр Дмитриевич', simonov@catalysis.ru}

\author{
Яковлев Вадим Анатольевич', \\ yakovlev@catalysis.ru \\ 1 Институт катализа им. Г.К. Борескова СО РАН, \\ Россия, 630090, г. Новосибирск, пр. ак. Лаврентьева, 5.
}

\begin{abstract}
Актуальность исследования обусловлена ежегодным образованием огромного количества нефтяных отходов (в основном нефтяных шламов и кислых гудронов). Развитие технологий переработки такого вида сырья является актуальным направлением исследования для многих научных коллективов. Несмотря на значительный вред для окружающей среды, отходы нефтепереработки заключают в себе огромный энергетический потенциал, в связи с чем необходимо создавать технологии, которые будут сочетать в себе как экологически чистую утилизацию, так и эффективное использование этого потенциала. На данный момент существует множество различных по своей природе способов утилизации рассматриваемых материалов. Основным из них является прямое сжигание отходов. Тем не менее практически все существующие подходы являются дорогостоящими и сложными в реализации. Кроме того, большинство из них не обеспечивают требуемой экологической безопасности процесса.

Цель: демонстрация применимости метода сжигания в кипящем слое катализатора к процессу эффективной утилизации отходов нефтепереработки.

Объекты: смеси нефть/вода различного соотношения компонентов, моделирующие отходы, образующиеся в результате процессов нефтепереработки (добычи, хранения, переработки в товарные продукты). Кроме того, исследованы образцы реальных отходов нефтепереработки - нефтешламы различного происхождения.

Методы: анализ литературных источников на предмет определения основных подходов к утилизации отходов нефтепереработки, используемых на практике; физические эксперименты по определению зольности, влажности и содержания летучих компонентов в исследуемых образцах; физический эксперимент по сжиганию модельных и реальных нефтяных отходов.

Результаты. Проведен анализ существующих методов термической переработки с достаточно подробным рассмотрением отдельных методов, применяемых на практике. Кроме того, была проведена серия физических экспериментов по сжиганию как модельных смесей нефть/вода в различном соотношении, так и реальных нефтяных шламов различного происхождения. Авторами работы показано, что сжигание как модельных, так и реальных нефтешламов в условиях кипящего слоя катализатора обеспечивает высокую экологическую безопасность процесса - содержание вредных выбросов $\left(\mathrm{CO}, \mathrm{NO}_{x}, \mathrm{SO}_{2}\right)$ не превышает уровень в 100 ppm. Кроме того, исследования показали возможность реализации автотермического режима горения рассматриваемых отходов, что позволяет максимально эффективно использовать их энергетический потенциал.
\end{abstract}

\section{Ключевые слова:}

Отходы нефтепереработки, сжигание, катализ, кипящий слой, автотермический режим, экологическая безопасность.

\section{Введение}

Одной из проблем, требующих к себе все больше внимания, является образование огромного количества отходов нефтепереработки (включающих в себя отходы добычи, хранения и транспортировки нефти), а именно необходимость их утилизации. Такие отходы являются одним из крупнейших источников загрязнения окружающей среды и оказывают серьезное негативное влияние как на экосистему в целом, так и на здоровье человека в частности [1-3]. В основном к отходам нефтепереработки относятся так называемые нефтяные шламы (НШ) и кислые гудроны (КГ). Состав данных продуктов нефтепереработки не является постоянной величиной, а варьируется в зависимости от многих факторов, таких как: конкретные условия добычи нефти, условия ее хранения, а также от специфики ее залегания в недрах. Тем не менее основными группами компонентов, составляющих отходы нефтепереработки, являются: нефтепродукты, вода, минеральные компоненты и механические примеси.

В зависимости от конкретных условий и вышеперечисленных факторов содержание в отходах нефтепереработки нефтепродуктов может варьироваться в пределах до $70 \%$, содержание воды до $85 \%$, содержание минеральных компонентов и механических примесей - до 50 \% . Как можно видеть, разброс данных показателей весьма высок и, к сожалению, не может давать четких представлений о той или иной составляющей нефтяных отходов.

По своему происхождению нефтяные отходы можно подразделить на несколько типов: 
- грунтовые - нефтепродукт, попавший в почву и пропитавший ее;

- природные - образующиеся в процессе оседания тяжелых компонентов нефти, например, на дно водоемов;

- резервуарного типа - образующиеся при хранении и транспортировке нефтепродуктов в цистернах, танках и других емкостях;

- отходы, образующиеся при добыче нефти - вещества, отделенные от сырой нефти вместе с механическими примесями, водой, минеральными солями и т. д.

По мнению экспертов и согласно существующим статистическим данным, от 3 до $5 \%$ всей добываемой в мире нефти уходит в отходы нефтепереработки и нефтедобычи [4-6]. Более 60 млн т отходов образуется в мире каждый год [7]. В Российской Федерации ежегодно образуется более 3 млн т нефтяных шламов и от 220 до 250 тыс. т кислых гудронов. Среди источников таких отходов можно выделить: нефтедобычу (более 1 млн т), нефтепереработку (порядка 0,7 млн т), нефтяные терминалы (около 0,3 млн т), а также другие источники: транспорт, аэропорты, морские порты и т. д. (около 0,5 млн т).

Проблемы утилизации НШ связаны с высоким содержанием в них воды (до 80 \%) и зольностью (до 50 \%). Утилизация кислых гудронов, содержащих значительные количества серной кислоты и олеума, методом прямого сжигания не приемлема из-за высоких выбросов $\mathrm{SO}_{2}$.

\section{Обзор методов утилизации}

Несмотря на значительные объемы образующихся нефтяных отходов, их разнообразие требует индивидуального подхода к их утилизации. На настоящий момент существует несколько способов обезвреживания и переработки нефтяных отходов [8-10]:

- Термический способ, включающий в себя различные виды сжигания, сушку либо пиролиз.

- Химический способ, заключающийся в затвердевании путем деспергирования с гидрофобными реагентами на основе негашеной извести или других материалов.

- Биологический способ - различные варианты биоразложения отходов путем введения в них бактерий, биогенных добавок и т. п.

- Физический способ, основанный на применении таких методов, как гравитационное отстаивание, разделение в центробежном поле, разделение фильтрованием и экстракция.

- Физико-химический способ, состоящий в применении специально подобранных поверхностно-активных веществ (деэмульгаторов, диспергаторов, смачивателей и т. д.).

Наиболее эффективным и универсальным, хотя и не всегда экономически рентабельным, считается термический метод обезвреживания нефтяных отходов [11-19]. Существует множество видов термической утилизации. Так, например, одним из таких способов является сжигание в печах барабанного типа $[12,13]$. Печь барабанного типа представляет собой цилиндрическую ёмкость, слегка наклонённую по горизонтали, которая медленно вращается вокруг своей оси. Вещество, которое будет обрабатываться, подаётся в верхнюю часть барабана. В то время как печь вращается, вещество плавно опускается и подвергается перемешиванию. Горячие газы проходят по печи в прямоточном направлении либо, чаще всего, в противоточном. Горячие газы могут появляться в выносной топке либо образуются от внутреннего пламени в печи. Это пламя выходит из трубы форсунки (печной форсунки). Барабанные печи могут иметь перегребающие и теплообменные устройства, а также специальные устройства для подачи твердых и газообразных материалов в отдельные зоны печи через отверстия в кожухе.

Один из примеров установок для сжигания нефтяных отходов, основанных на применении барабанной печи, описан в [12]. Описанная установка предназначена для утилизации путем сжигания нефтешламов, замазученых грунтов, нефтесодержащих отходов, образующихся при аварийных разливах нефти и нефтепродуктов, отработанных масел, в т. ч. растительного происхождения. На установке допускается утилизация отходов с содержанием нефти и нефтепродуктов в шламе не более 30 \% . При более высоком содержании нефтепродукта необходимо понизить его концентрацию добавлением в него грунта (песка). Процесс сжигания нефтесодержащих отходов проводится при рабочей температуре $600-800{ }^{\circ} \mathrm{C}$. Температура отходящих газов в атмосферу составляет $100-110{ }^{\circ} \mathrm{C}$. Сжигание отходов проводится в присутствии большого избытка воздуха.

К достоинствам данного способа следует отнести сравнительно низкий температурный диапазон проведения процесса сжигания, позволяющий снизить выброс токсичных веществ в атмосферу. Функционирование в данном диапазоне также снижает требования к используемым конструкционным материалам. Недостатком данной технологии является повышенное потребление энергетических ресурсов (вследствие использования обводненных нефтеотходов). Кроме того, процесс требует использования больших избытков воздуха. При этом конечный продукт переработки не находит дальнейшего применения [12].

Другим способом сжигания нефтяных отходов, используемых в настоящее время, является сжигание в различных печах (чаще всего камерных) с использованием форсунок для подачи топлива в печь. Так, на заводе «НижегородГИПРОнефтехим» была разработана технологическая схема сжигания нефтяных отходов [14]. Согласно данной схеме, нефтяные отходы предварительно отстаиваются в специальной емкости для удаления избыточной воды и, частично, остатков нефтепродуктов. Отстоявшиеся отходы перемешиваются и подаются в усреднительные емкости, в которых под- 
держивается их постоянный состав и происходит нагрев до 60-80 ․ Затем через ротационную форсунку отходы поступают в печь, где при температуре $1000-1200{ }^{\circ} \mathrm{C}$ происходит полное сгорание органической части.

Широкое применение также находит сжигание в топках с барботажными горелками [15]. Барботаж подразумевает под собой продувку через слой топлива газообразного агента, например, воздуха. В горелках барботажного типа функции распыливающего устройства выполняет пенный слой. Все пространство распыливания в них можно разделить на три зоны: зону пенного слоя, где происходит распределение обводненного топлива в потоке «первичного» воздуха в виде тонких пленок, разделяющих воздушные пузырьки; зону формирования капель, в которой происходит разрушение пенного слоя; зону стабилизации, представляющую собой сформировавшуюся область дисперсного состава жидкого топлива с постоянной концентрацией капелек топлива в потоке подаваемого сюда «вторичного» воздуха. Барботаж воздуха или горючего газа через слой нефтепродуктов способствует повышению эффективности процессов тепломассообмена. В процессе горения обводненный слой жидких нефтеотходов в барботажной ванне, через который продувается «первичный» воздух, прогревается до температуры кипения. Взаимодействие образующихся горючих паров с кислородом происходит в зоне горения над слоем, куда непрерывно должны поступать горючие пары и вторичный воздух. Тепло от зоны горения к поверхности нефтеотходов передается посредством конвекции и теплового излучения.

Недостатком всей технологии является дорогостоящая система очистки газов, образующихся в ходе процесса, поскольку сжигание предварительно не очищенных масел сопровождается образованием большого количества золы и высокотоксичных отходящих газов (монооксид углерода, углеводороды, оксиды серы).

Еще одним вариантом термической утилизации нефтяных отходов является сжигание в печах с кипящим слоем теплоносителя $[16,17]$. Печь с кипящем слоем представляет собой вертикальный цилиндрический реактор, в котором находятся частицы ожижаемого материала. Процесс псевдоожижения происходит благодаря восходящему потоку воздуха, подаваемому в нижнюю часть реактора. В слой кипящего материала сверху либо через боковые отверстия подается сжигаемое вещество. Через отверстие в верхней части реактора происходит вынос отходящих газов и продуктов процесса горения. В общем виде процесс сжигания отходов в установках с кипящим слоем теплоносителя представлен на рис. 1.

В мировой практике ведущими компаниями, использующими технологию сжигания топлив и отходов в кипящем слое теплоносителя, являются: «Lurgi AG» (Германия), «Ebara» (Япония), «Foster Wheeler» (США). Однако в большинстве своем тех- нологии данных компаний направлены на переработку и утилизацию мусора и твердых бытовых отходов и не находят широкого применения в термической переработке нефтяных отходов.

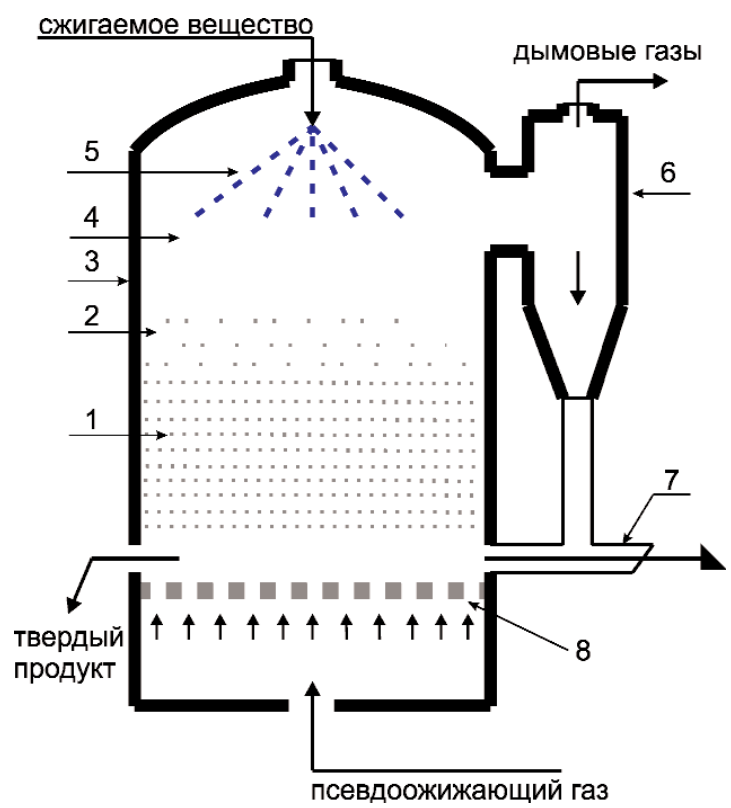

Pис.1. Схема работы печи с псевдоожиженным слоел: 1 - плот ная фаза ожиженного слоя; 2 - разбавленная фаза ожи женного слоя; 3 - печь; 4 - распыленный загруженный ма териал; 5 - калера; 6 - ииклонный сепаратор; 7 - труба для возврата материалов; 8 -газораспределительная решетка

Fig. 1. Scheme of the fluidized bed furnace: 1 is the dense phase of the fluidized bed; 2 is the diluted phase of the fluidized bed; 3 is the furnace; 4 is the sprayed feedstock; 5 is the chamber; 6 is the cyclone separator; 7 is the tube for materials returning; 8 is the gas distribution grid

В России на предприятиях нефтеперерабатывающей промышленности было построено несколько печей с кипящим слоем для сжигания нефтешламов. Одна из таких установок эксплуатировалась на Уфимском НПЗ. Печь представляла собой вертикальный цилиндрический аппарат, футерованный изнутри огнеупорным кирпичом диаметром 2,6 м, высотой 8 м. В качестве материала для создания кипящего слоя применялся кварцевый песок с размером фракции 0,8 мм, высота слоя составляла 800-1000 м. Температура кипящего слоя рекомендовалась в пределах $600{ }^{\circ} \mathrm{C}$, подогрев его осуществлялся топливными форсунками, расположенными как в слое, так и под слоем. Псевдоожижение слоя песка создавалось холодным воздухом. Эксплуатация данной печи привела к отрицательным результатам. Причиной этому послужило то, что предварительно подогретый до $600{ }^{\circ} \mathrm{C}$ слой песка периодически остывал до 400-450 ${ }^{\circ} \mathrm{C}$. При данной температуре в слое песка горение прекращалось, шли процессы крекинга и коксования, т. е. газификация шлама, что приводило к образованию коксовых агломератов и закупориванию кипящего слоя [15]. В то же время при 
правильном выборе объекта обезвреживания и соблюдении технологических режимов печи кипящего слоя работают надежно и эффективно.

Технология сжигания нефтяных отходов в кипящем слое теплоносителя имеет безусловные преимущества перед слоевым или факельным горением топлив по своей эффективности и количеству токсичных выбросов. Однако и в этом случае содержание токсичных примесей в дымовых газах заметно превышает санитарные нормы.

Как видно, существует множество способов термической переработки нефтяных отходов. Однако все они обладают существенными недостатками, среди которых можно отметить: несоответствие современным экологическим требованиям к токсичности выбросов, производимых в процессе сжигания, и требованиям к энергосбережению; экономическая нерентабельность эксплуатации установок; ограничения по типу и свойствам сжигаемых отходов; высокие требования к используемым материалам при создании установок; высокие требования к обслуживанию; неэффективность сжигания отходов и другие. Рассматриваемая в данной работе технология сжигания нефтяных отходов в кипящем слое катализатора устраняет практически все недостатки существующих способов сжигания, обладает значительными преимуществами и на сегодняшний день не имеет аналогов, как в Российской Федерации, так и за рубежом.

\section{Материалы и методы}

Анализ исходного углеводородного сырья

Для исходного сырья и продуктов окисления определялись: плотность, зольность, влажность, элементный состав, количество летучих компонентов.

Плотность определялась при помощи ареометра (ГОСТ 3900-85).

Содержание в исходных нефтешламах и сырой нефти таких элементов, как сера, водород, азот и углерод, определяли на приборе CHNS элементный анализатор VARIO EL CUBE производства фирмы Elementar Analysensysteme GmbH, Germany. Принцип действия анализатора основан на каталитическом сжигании при высокой температуре предварительно взвешенной анализируемой пробы, очистке, осушке, адсорбционном разделении продуктов сгорания, и последующем детектировании катарометром.

Дополнительно, для экспресс-определения содержания серы, применялся метод рентгенофлюоресцентного анализа на анализаторе ARL-Advant'x c $\mathrm{Rh}$ - анодом рентгеновской трубки (ГОСТ Р 51947-2002). Принцип метода заключается в том, что испытуемый образец помещается в пучок лучей, испускаемых источником рентгеновского излучения. Затем измеряются характеристики энергии возбуждения от рентгеновского излучения и сравниваются полученные сигналы счетчика импульсов с сигналами счетчика, полученными при испытании заранее подготовленных калибровочных образцов.
Зольность образцов до сжигания определялась согласно ГОСТ 1461-75 (Нефть и нефтепродукты. Метод определения зольности). Сущность данного метода заключается в том, что пробу топлива сжигают в муфельной печи, нагреваемой с определенной скоростью до температуры $775 \pm 25{ }^{\circ} \mathrm{C}$, и выдерживают при этой температуре до постоянной массы. Зольность в процентах рассчитывают по массе остатка после прокаливания, согласно формуле:

$$
A=\frac{m_{1}-m_{2}}{m} \cdot 100,
$$

где $m$ - масса испытуемого продукта, г; $m_{1}$ - масса золы, г; $m_{2}$ - масса золы двух бумажных фильтров, г.

Содержание воды в исходных образцах определялось одноступенчатым методом по ГОСТ Р 52911-2008. Навеску пробы высушивают в сушильном шкафу при $105-110{ }^{\circ} \mathrm{C}$ в атмосфере воздуха до постоянной массы. Массовую долю воды рассчитывают по потере массы навески, согласно формуле:

$$
W_{t}=\frac{m_{2}-m_{3}}{m_{2}-m_{1}} \cdot 100
$$

где $m_{1}$ - масса пустого бюкса с крышкой, г; $m_{2}-$ масса бюкса с крышкой и пробой до сушки, г; $m_{3}-$ масса бюкса с крышкой и пробой после сушки, г.

Содержание нефтепродуктов в рабочей массе нефтешламов определялось из общей массы нефтешлама за вычетом массы воды и зольного компонента.

\section{Анализ газообразных продуктов окисления}

углеводородного сырья

Продукты сжигания топлив в кипящем слое катализатора можно разделить на две составляющие - газообразные продукты сжигания и зола. Анализ отходящих газов производился при помощи газоанализатора «ПОЛАР», соответствующего ГОСТ Р 50759-95. Принцип действия газоанализатора основан на применении комплекта электрохимических и оптических датчиков для измерения содержания газовых компонент анализируемой пробы, термоэлектрического преобразователя (термопары) типа «К» для измерения температуры газового потока, дифференциального полупроводникового датчика для измерения избыточного давления (разрежения) и в комплекте с пневмометрической напорной трубкой типа Пито или НИИОГАЗ для определения скорости и объемного расхода газового потока. Прибор предназначен для определения концентрации таких газов, как кислород, $\mathrm{CO}_{2}, \mathrm{CO}, \mathrm{NO}$ и $\mathrm{NO}_{2}, \mathrm{SO}_{2}$, а также углеводородов.

\section{Анализ твердых продуктов окисления углеводородного сырья}

Для твердых продуктов окисления углеводородного сырья определялись такие характеристики, как зольность, степень выгорания, элементный состав. 
Зольность продуктов окисления определялась по ГОСТ 11022-95, аналогично случаю анализа исходного углеводородного сырья.

Исходя из значения зольности сырья и зольности конечного продукта окисления, определялась степень выгорания органической составляющей сырья. Степень выгорания горючей массы топлива определялась по формуле:

$$
\beta(\%)=10000\left(A_{\mathrm{ocr}}^{\mathrm{c}}-A_{0}^{\mathrm{c}}\right) / A_{\mathrm{ocT}}^{\mathrm{c}}\left(100-A_{0}^{\mathrm{c}}\right),
$$

где $A_{0}^{\mathrm{c}}$ - исходная зольность сухого топлива, \%; $A_{\text {ост }}^{\mathrm{c}}$ - зольность сухого остатка, \% .

Как и в случае с исходным углеводородным сырьем, элементный анализ продуктов окисления осуществлялся при помощи рентгенофлюоресцентного анализа.

\section{Катализатор глубокого окисления для кипящего слоя}

Для исследования сжигания реальных и модельных нефтешламов в реакторе кипящего слоя был использован катализатор ЩКЗ-1. Катализатор представляет собой шариковый гамма-оксид алюминия с нанесенными на поверхность оксидами меди и хрома (активный компонент). Предшественники активного компонента были нанесены методом пропитки исходного носителя по влагоемкости. Состав и характеристики катализатора приведены в табл. 1.

Таблица 1. Состав и характеристики катализатора

Table 1. Composition and characteristics of the catalyst

\begin{tabular}{|c|c|c|c|c|c|}
\hline $\begin{array}{c}\text { Катали- } \\
\text { затор } \\
\text { Catalyst }\end{array}$ & \begin{tabular}{|c} 
Удельная \\
поверх- \\
ность, $\mathrm{m}^{2} / \Gamma$ \\
Specific sur- \\
face, $\mathrm{m}^{2} / \mathrm{g}$
\end{tabular} & $\begin{array}{c}\text { Объем } \\
\text { пор, } \mathrm{cm}^{3} / г \\
\text { Pore vo- } \\
\text { lume, } \\
\mathrm{cm}^{3} / \mathrm{g}\end{array}$ & 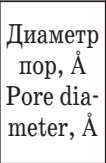 & $\begin{array}{c}\text { Элемент- } \\
\text { ный состав } \\
\text { Elemental } \\
\text { composition }\end{array}$ & $\begin{array}{c}\text { Фазовый } \\
\text { состав } \\
\text { Phase } \\
\text { composition }\end{array}$ \\
\hline $\begin{array}{c}\text { ЩК-1 } \\
\text { ShchKZ-1 }\end{array}$ & 115 & 0,30 & 105 & $\begin{array}{c}6,5 \% \mathrm{Cr}_{2} \mathrm{O}_{3} \\
3,5 \% \mathrm{CuO}\end{array}$ & $\begin{array}{c}\mathrm{CuCr}_{2} \mathrm{O}_{4}, \\
\text { (следы/ } \\
\text { traces) } \\
\gamma-\mathrm{Al}_{2} \mathrm{O}_{3} \\
\end{array}$ \\
\hline
\end{tabular}

\section{Сжигание топлив в кипящем слое катализатора}

Для сжигания в кипящем слое катализатора жидких топлив, таких как тяжелая высокосернистая нефть и нефтешламы, в работе использовалась установка, представленная на рис. 2. Из специальной емкости при помощи насоса топливо через боковое отверстие в нижней части, продуваемое воздухом, подается в реактор с кипящим слоем, диаметром 40 мм. Кроме того, установка оснащена узлом подачи твердого связующего соединений серы из бункера в реактор при помощи шнекового дозатора.

\section{Результаты и обсуждение}

Проводилось исследование сжигания модельного нефтешлама, а также промышленных нефтешламов, образующихся при переработке нефти на Рязанском нефтеперерабынывающем заводе (РНПЗ). Исследовались два типа шламов - шлам из шламонакопителя плавающий (ШНП) и шлам из нефтеловушки (ШНЛ).
Смесь, моделирующая нефтяной шлам, была приготовлена путем смешивания тяжелой высокосернистой нефти и воды в соотношении 1:1. При помощи диспергатора ULTRA TURRAX T25 BASIC (IKA-WERKE, Германия) смесь переводилась в устойчивую однородную по объему эмульсию. В реактор эмульсия подавалась через форсунку, в которую параллельно дозировалась вода для варьирования ее содержания в конечной смеси на входе в реактор. Сжигание модельной смеси проводилось в автотермическом режиме при $700{ }^{\circ} \mathrm{C}$. Такие условия позволяют определить возможность проведения автотермического сжигания такого вида сырья при различной исходной влажности.

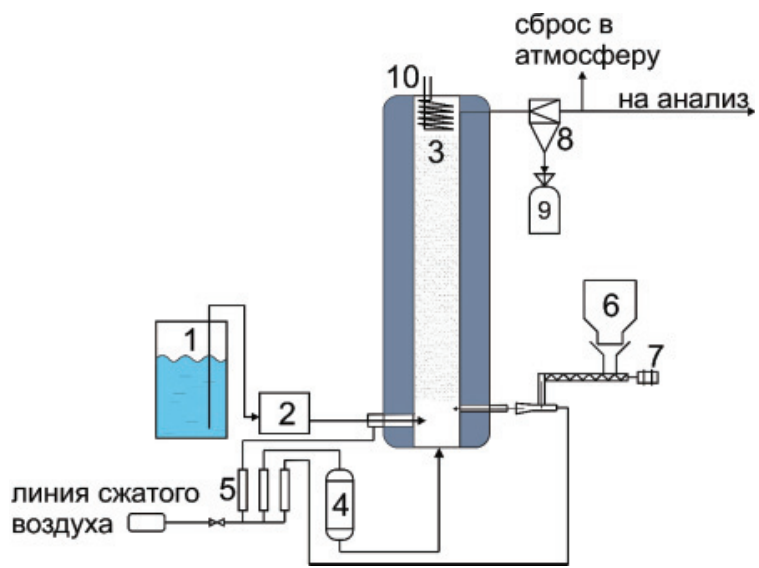

Pис. 2. Установкадлясжиганияжидких топлив в кипящем слое катализатора: 1 - елкость с жидким топливом; 2 - насос; 3-реактор; 4-воздухонагреватель; 5-ротаметры; 6 -бункер с твердыл связующил; 7 - шнековый дозатор; 8 - ииклон; 9 - емкость для сбора золь; 10 - теплообменник

Fig. 2. Installation for combustion of liquid fuels in a fluidized bed of catalyst: 1 is the tank with liquid fuel; 2 is the pump; 3 is the reactor; 4 is the heater; 5 are the rotameters; 6 is the tank with solid absorbent; 7 is the screw feeder; 8 is the cyclone; 9 is the ash collector; 10 is the heat exchanger

Сжигание нефтяного сырья проводилось на установке, представленной на рис. 2. В реактор, снабжённый организующей насадкой, загружался катализатор глубокого окисления ЩКЗ-1 $\left(\mathrm{CuCr}_{2} \mathrm{O}_{4} / \gamma-\mathrm{Al}_{2} \mathrm{O}_{3}\right)$ с размером сферических частиц $1,2-1,4$ мм в количестве $500 \mathrm{~cm}^{3}$. В качестве катализатора глубокого окисления для процесса был выбран именно ЩКЗ-1, поскольку данный катализатор проявляет максимальное значение каталитической активности в отношении окисления $\mathrm{CO}$, являющегося основным вредным выбросом, образующимся при горении нефтяного сырья.

Состав использовавшихся в работе нефтешламов и модельной смеси представлен в табл. 2.

При сжигании модельной смеси и нефтешламов в кипящем слое катализатора ЩКЗ-1 при $700{ }^{\circ} \mathrm{C}$ в отходящих газах продуктов недожога не наблюдалось. Кроме того, содержание токсичных веществ в отходящих газах, таких как $\mathrm{NO}, \mathrm{NO}_{2}, \mathrm{SO}_{2}$, находилось на незначительном уровне (рис. 3 ). 
Таблииа 2. Состав нефтяного сырья

Table 2. Oil feedstock composition

\begin{tabular}{|c|c|c|c|}
\hline \multirow[t]{2}{*}{$\begin{array}{c}\text { Сырье } \\
\text { Feedstock }\end{array}$} & $\begin{array}{c}\text { Содержание } \\
\text { воды } \\
\text { Water content, } \\
\mathrm{W}^{\mathrm{p}}\end{array}$ & $\begin{array}{c}\text { Зольность } \\
\text { рабочей массы } \\
\text { Ash content, } \mathrm{A}^{\mathrm{p}}\end{array}$ & \begin{tabular}{|c|} 
Нефтепродукты \\
в рабочей массе, \\
HПР \\
Oil products \\
content \\
\end{tabular} \\
\hline & \multicolumn{3}{|c|}{$\%$} \\
\hline $\begin{array}{c}\text { Модельная смесь } \\
\text { Model mixture }\end{array}$ & $50,0-80,0$ & 0 & $20,0-50,0$ \\
\hline $\begin{array}{c}\text { ШНП } \\
\text { Floating sludge }\end{array}$ & 80,5 & 0,6 & 18,9 \\
\hline $\begin{array}{c}\text { ШНЛ } \\
\text { Oil trap sludge }\end{array}$ & 86,3 & 4,9 & 8,8 \\
\hline
\end{tabular}

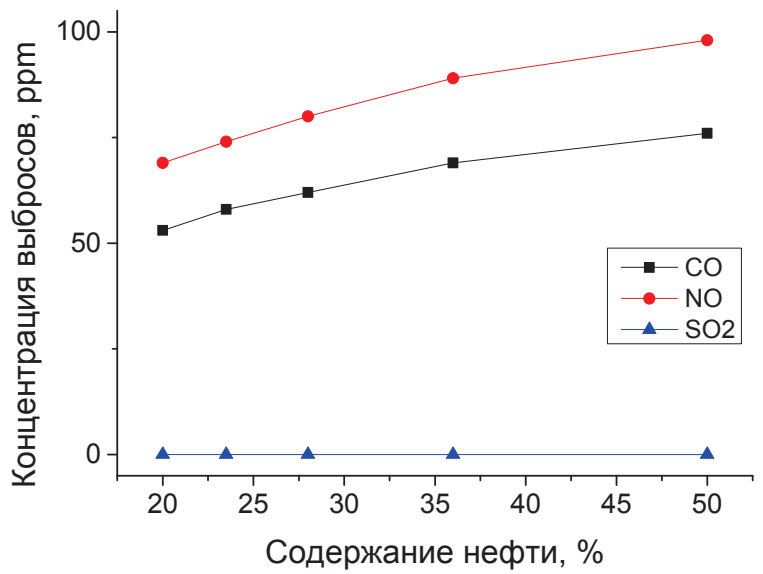

Рис.3. Результаты сжигания модельного нефтешлама при $700^{\circ} \mathrm{C}$ в автотерлическом режиме

Fig. 3. Results of model oil sludge combustion at $700^{\circ} \mathrm{C}$ in autothermal mode

Из полученных данных видно, что при увеличении содержания нефти в модельном нефтешламе растет уровень выбросов $\mathrm{CO}$ и $\mathrm{NO}_{x}$. Это обусловливается большим количеством органического сырья, проходящим через реактор в единицу времени. Тем не менее количество образующихся оксидов азота и $\mathrm{CO}$ не превосходит предельно допустимые значения для данных процессов. Количество $\mathrm{SO}_{2}$ на выходе из реактора остается близким к нулю вследствие эффективного связывания образующихся оксидов серы с оксидами, входящими в состав катализатора [20].

Для каждого соотношения нефть/вода и для реальных нефтешламов была определена величина степени выгорания. Степень выгорания нефтешламов при $700{ }^{\circ} \mathrm{C}$ составила 99,6\% для ШНП, $99,4 \%$ - для ШНЛ и 99,8 \% - для модельной смеси нефть/вода. Таким образом, можно утверждать, что процесс сжигания нефтешламов в кипящем слое катализатора протекает с высокой эффективностью в отношении полезного использования органической составляющей топлива.

Полученные в результате исследований данные были использованы для расчета оптимальных условий сжигания реальных нефтешламов в установках кипящего слоя катализатора. Расчет теплового баланса показал, что при сжигании ШНП в системе будет происходить выделение дополнительной теплоты (свыше количества, необходимого для реализации автотермического режима горения) в количестве 505 ккал на 1 кг сжигаемого продукта. Поэтому при сжигании ШНП необходимо обеспечить отвод избытка теплоты. В случае сжигания ШНЛ для обеспечения температурного режима $700{ }^{\circ} \mathrm{C}$ необходимо добавочное топливо. При использовании, например, нефти с теплотворной способностью 9800 ккал/кг расход нефти составит 0,024 кг на 1 кг сжигаемого нефтешлама. При совместном сжигании шламов возможно создание автотермического режима без дополнительного топлива, при этом весовое соотношение ШНП/ШНЛ=0,46. Данное соотношение соответствует средней влажности 80-85 \% и калорийности 900-1000 ккал/кг.

Таким образом, сжигание в кипящем слое катализатора таких некондиционных видов топлива, как нефтяные шламы, является не только высокоэффективным, но и экологически безопасным. Реализация данного процесса позволит не только решить проблему утилизации образующихся в огромном количестве нефтяных отходов, обеспечив при этом необходимую экологическую безопасность процесса, но и совместить процесс утилизации с получением рабочего тепла от сжигания.

\section{Заключение}

Таким образом, разработанная в Институте катализа СО РАН технология сжигания топлив и отходов в псевдоожиженном слое катализатора может быть эффективно применена для экологически безопасного сжигания отходов нефтедобычи и нефтепереработки. Приведенные в работе результаты показывают, что наряду с высокой степенью выгорания исходного нефтяного сырья содержание в дымовых газах $\mathrm{CO}, \mathrm{NO}_{\mathrm{x}}, \mathrm{SO}_{\mathrm{x}}$ не превышает санитарных норм.

Сжигание модельного обводненного нефтешлама в кипящем слое катализатора возможно в автотермическом режиме горения при содержании воды до $80 \%$ с достижением степени выгорания 99,8 \% . При сжигании промышленных нефтешламов при $700{ }^{\circ} \mathrm{C}$ показана возможность реализации автотермического режима при влажности 80-85 \% и калорийности 900-1000 ккал/кг. При этом обеспечивается 99,5\% степени выгорания, а содержание $\mathrm{CO}$, оксидов азота и $\mathrm{SO}_{2}$ в отходящих газах не превышает $100 \mathrm{ppm}$, что существенно ниже, чем ПДВ.

Работа выполнена при финансовой поддержке РНФ (проект № 17-73-30032). 


\section{СПИСОК ЛИТЕРАТУРЫ}

1. Morsali S. A novel perspective to bitumen refineries life cycle assessment and processes emissions // Acta Ecologica Sinica. 2018. - V. 38. - Iss. 3. - P. 242-247.

2. Gupta A.K., Ahmad I., Ahmad M. Genotoxicity of refinery waste assessed by some DNA damage tests // Ecotoxicology and Environmental Safety. - 2015. - V. 114. - P. 250-256.

3. Toxicity Assessment of Carbon Black Waste: A by-Product from Oil Refineries / X. Zhen, W.C. Ng, Fendy, Y.W. Tong, Y. Dai, K.G. Neoh, C.-H. Wang // J. Hazard. Mater. - 2017. - V. 321. P. $600-610$

4. Хаустов А.П., Редина М.М. Экологические проблемы оценки образования нефтешламов при авариях // Экологический вестник России. - 2011. - № 8. - С. 34-37.

5. Шлапаков А.В. Утилизация нефтешлама в Венесуэле // Экология производства. - 2012. - № 7. - С. 81-85.

6. Воробьев Ю.Л., Акимов В.А., Соколов Ю.И. Предупреждение и ликвидация аварийных разливов нефти и нефтепродуктов. М.: Ин-октаво, 2005. - 368 с.

7. Enrichment and characterization of hydrocarbon-degrading bacteriafrom petroleum refinery waste as potent bioaugmentation agent for in situ bioremediation / P. Sarkar, A. Roy, S. Pal, B. Mohapatra, S.K. Kazy, M.K. Maiti, P. Sar // Bioresource Technology. - 2017. - V. 242. - P. 15-27.

8. Красногорская Н.Н., Магид А.Б., Трифонова Н.А. Утилизация нефтяных шламов // Нефтегазовое дело. - 2004. - Т. 2. C. 217-222.

9. Speight J., El-Gendy N.S. Introduction to Petroleum Biotechnology. $1^{\text {st }}$ ed. - Houston: Gulf Professional Publishing, 2017. $566 \mathrm{p}$.

10. Fink J. Guide to the Practical Use of Chemicals in Refineries and Pipelines. $1^{\text {st }}$ ed. - Houston: Gulf Professional Publishing, 2016. $-266 \mathrm{p}$

\section{Информация об авторах}

Дубинин Ю.В., кандидат химических наук, научный сотрудник лаборатории каталитических процессов переработки возобновляемого сырья Института катализа им. Г.К. Борескова СО РАН.

Языков Н.A., кандидат химических наук, научный сотрудник лаборатории каталитических процессов переработки возобновляемого сырья Института катализа им. Г.К. Борескова СО РАН.

Симонов А.Д., кандидат химических наук, ведущий инженер-технолог лаборатории каталитических процессов переработки возобновляемого сырья Института катализа им. Г.К. Борескова СО РАН.

Яковлев В.А., доктор химических наук, заместитель директора по научной работе Института катализа им. Г.К. Борескова СО РАН.
11. Мазлова Е.А., Мещеряков С.В. Проблемы утилизации нефтешламов и способы их переработки. - М.: Ноосфера, 2001. $56 \mathrm{c.}$

лагутенко М.А. Направления совершенствования технологии термического обезвреживания нефтесодержащих отходов // Сучный журнал КубГАУ. - 2013. - № 93. - С. 1-14. В.В. Фрязинов, Б.И. Брондз, В.А. Расветалов и др. - М.: ЦНИИТЭнефтехим, $1985 .-64$ с.

Тимонин А.С. Инженерно-экологический справочник. Т. 3. Калуга: Изд-во Н. Бочкаревой, 2003. - 1024 с.

. Пальгунов П.П., Сумароков М.В. Утилизация промышленных отходов. - М.: Стройиздат, 1990. - 352 с.

Пономарев В.Г., Иоакимис Э.Г., Монгайт И.л. Очистка сточных вод нефтеперерабатывающих заводов. - М.: Химия, 8. -256 c.

17. Баскаков А.П., Мацнев В.В., Распопов И.В. Котлы и топки с кипящим слоем. - М.: ЭАИ, 1995. - 350 с.

18. Испытания горелочного устройства беспламенного горения и инфракрасного излучения / С.В. Долгов, А.С. Заворин, А.Ю. Долгих, А.Н. Субботин // Известия Томского политехнического университета. - 2013. - Т. 322. - № 4. - С. 39-42.

19. Adánez J., Abad A. Chemical-looping combustion: Status and research needs // Proceedings of the Combustion Institute. 2018. - V. 37. - № 4. - P. 4303-4317.

20. Features of Sulfur Oils Catalytic Combustion in Fluidized Bed / N.A. Yazykov, Y.V. Dubinin, A.D. Simonov, S.I. Reshetnikov, V.A. Yakovlev // Chemical Engineering Journal. - 2016. V. 283. - P. 649-655.

Поступила 16.11.2018 г.
. Сжигание нефтешламов и активных илов на НПЗ: Тем. обз. / 


\title{
COMBUSTION OF MODEL AND REAL OIL SLUDGE IN A FLUIDIZED BED OF CATALYST
}

\author{
Yury V. Dubinin',
}

dubinin@catalysis.ru

Nikolay A. Yazykov',
yazykov@catalysis.ru

Alexander D. Simonov', simonov@catalysis.ru

Vadim A. Yakovlev',
yakovlev@catalysis.ru
'Boreskov institute of catalysis SB RAS,
5, Academician Lavrentiev avenue, Novosibirsk, 630090, Russia.

The relevance of the research is caused by generation of a huge amount of oil refinery waste (mainly oil sludge and acid tars). The development of technologies for processing such type of raw materials is an important area for many research teams. Despite the significant harm to the environment, refining waste contains a huge energy potential. Therefore, it is necessary to create technologies that will combine both environmentally friendly recycling and effective use of this potential. Now, there are many different ways of such materials utilization. The main one is direct combustion. However, almost all existing approaches are expensive and difficult in their implementation. In addition, most of them do not provide the required environmental safety of the process.

The main aim of the research is to demonstrate the applicability of the fluidized bed combustion method for efficient refinery waste utilization.

Objects of the research are the oil/water mixtures of various component ratio modeling waste resulting from refining processes (production, storage, processing into commodity products). In addition, samples of real oil refining waste (oil sludge of various origin) were investigated.

Methods: analysis of literary sources in order to determine the main approaches to oil waste utilization; physical experiments to determine ash, moisture and volatile content in the samples; physical experiment on combustion of model and real oil waste.

Results. The paper analyzes the existing methods of thermal processing with a sufficiently detailed consideration of individual methods used in practice. In addition, a series of physical experiments on combustion of both model oil/water mixtures in various ratios and real oil sludges of various origin was carried out. The authors showed that the combustion of both model and real sludge under conditions of a fluidized bed of catalyst provides a high environmental safety of the process - the content of harmful emissions $\left(\mathrm{CO}_{1} \mathrm{NO}_{\mathrm{x}}, \mathrm{SO}_{2}\right)$ does not exceed $100 \mathrm{ppm}$. In addition, the studies have shown the possibility of implementing the autothermal mode of combustion, which allows one to use their energy potential in most efficient way.

Key words:

Oil sludge, combustion, catalysis, fluidized bed, autothermic mode, ecological safety.

The research was financially supported by the RSF (project no. 17-73-30032).

\section{REFERENCES}

1. Morsali S. A novel perspective to bitumen refineries life cycle assessment and processes emissions. Acta Ecologica Sinica, 2018, vol. 38, Iss. 3, pp. 242-247.

2. Gupta A.K., Ahmad I., Ahmad M. Genotoxicity of refinery waste assessed by some DNA damage tests. Ecotoxicology and Environmental Safety, 2015, vol. 114, pp. 250-256.

3. Zhen X., Ng W.C., Fendy, Tong Y.W., Dai Y., Neoh K.G., Wang C.-H. Toxicity Assessment of Carbon Black Waste: A byProduct from 0il Refineries. J. Hazard. Mater, 2017, vol. 321, pp. 600-610.

4. Khaustov A.P., Redina M.M. Environmental problems of assessing the formation of oil sludge during accidents. Ecological Bulletin of Russia, 2011, no. 8, pp. 34-37. In Rus.

5. Shlapakov A.V.. Utilizatsya nefteshlama v Venesuele [Utilization of oil sludge in Venezuela]. Ekologiya proizvodstva, 2012, no. 7, pp. $81-85$

6. Vorobiev Yu.L., Akimov V.A., Sokolov Yu.I. Preduprezhdenie $i$ likvidatsya avariynykh razlivov nefti i nefteproduktov [Prevention and elimination of accidental spills of oil and oil products]. Moscow, In-octavo Publ., 2005. 368 p.
7. Sarkar P., Roy A., Pal S., Mohapatra B., Kazy S.K., Maiti M.K., Sar P. Enrichment and characterization of hydrocarbon-degrading bacteriafrom petroleum refinery waste as potent bioaugmentation agent forin situ bioremediation. Bioresource Technology, 2017, vol. 242, pp. 15-27.

8. Krasnogorskaya N.N., Magid A.B., Trifonova N.A. Utilizatsyia neftyanykh shlamov [Utilisation of oil sludge]. Neftegazovoe delo, 2004, vol. 2, pp. 217-222.

9. Speight J., El-Gendy N.S. Introduction to Petroleum Biotechnology. $1^{\text {st }}$ ed. Houston, Gulf Professional Publishing, 2017. 566 p.

10. Fink J. Guide to the Practical Use of Chemicals in Refineries and Pipelines. $1^{\text {st }}$ ed. Houston, Gulf Professional Publishing, 2016. $266 \mathrm{p}$.

11. Mazalova E.A., Mesheryakov S.V. Problemy utilizatsii nefteshlamov i sposoby ikh pererabotky [Problems of sludge utilization and methods for their processing]. Moscow, Noosfera, 2001. 56 p.

12. Lagutenko M.A. Directions for improving the technology of oily waste thermal disposal. Scientific journal of KubSAU, 2013, no. 93, pp. 1-14. In Rus.

13. Fryazinov V.V., Brondz B.I., Rasvetalov V.A. Szhiganie nefteshlamov $i$ aktivnykh ilov na NPZ: Tem. obz. [Combustion of oil 
sludge and activated sludge at refineries: Topics. Reviews]. Moscow, TSNIITEneftekhim Publ., 1985. 64 p.

14. Timonin A.S. Inzhenerno-ekologichesky spravochnik [Engineering-ecological Handbook]. Kaluga, N. Bochkareva Publ. House, 2003. Vol. 3, 1024 p.

15. Palgunov P.P., Sumarokov M.V. Utilizatsiya promyshlennykh otkhodov [Industrial waste utilization]. Moscow, Stroiizdat Publ., 1990. $352 \mathrm{p}$.

16. Ponomarev V.G., Ioakimis E.G. Mongait I.L. Ochistka stochnykh vod neftepererabatyvayuschikh zavodov [Wastewater treatment of refineries]. Moscow, Khimiya Publ., 1985. 256 p.

17. Baskakov A.P., Mantsev V.V., Raspopov I.V. Kotly i topki s kipashchim sloem [Fluidized bed boilers and furnaces]. Moscow, EAI Publ., 1995. 350 p.

\section{Information about the authors}

Yury V. Dubinin, Cand. Sc., researcher, Boreskov institute of catalysis SB RAS.

Nikolay A. Yazykov, Cand. Sc., researcher, Boreskov institute of catalysis SB RAS.

Alexander D. Simonov, Cand. Sc., engineer, Boreskov institute of catalysis SB RAS.

Vadim A. Yakovlev, Dr. Sc., Deputy Director, Boreskov institute of catalysis SB RAS.
18. Dolgov S.V., Zavorin A.S., Dolgikh A.Yu., Subbotin A.N. Tests of burner device of flameless combustion and infra-red radiation. Bulletin of the Tomsk Polytechnic University, 2013, vol. 322, no. 4, pp. 39-42. In Rus.

19. Adánez J., Abad A. Chemical-looping combustion: Status and research needs. Proc. of the Combustion Institute, 2018, vol. no. pp. 1-15.

20. Yazykov N.A., Dubinin Y.V., Simonov A.D., Reshetnikov S.I., Yakovlev V.A. Features of Sulfur Oils Catalytic Combustion in Fluidized Bed. Chemical Engineering Journal, 2016, vol. 283, pp. 649-655.

Received: 16 November 2018. 